\title{
Refinement of Fertilizer Prescription Equations for Hybrid Maize under Integrated Plant Nutrient System on an Inceptisol
}

\author{
C. Sivaranjani", K.M. Sellamuthu and R. Santhi \\ Department of Soil Science and Agricultural chemistry, Directorate of Natural Resource \\ Management, Tamil Nadu Agricultural University, Coimbatore-3, Tamil Nadu, India \\ *Corresponding author
}

\section{A B S T R A C T}

In order to refine the fertiliser prescription equation for hybrid maize on an Inceptisol (Periyenackampalayam soil series-Vertic Ustropept), a field experiment was conducted at

Keywords

Inductive cum target yield model, Maize, STCR-IPNS

Article Info

Accepted:

28 January 2018

Available Online:

10 February 2018 farmer's holding of Allapalayam village, Annur block, Coimbatore District of Tamil Nadu in Western Zone of Tamil Nadu during Rabi 2015-16. Basic parameters were calculated from the data generated from the field experiment. Using the basic parameters, crop nutrient requirement per quintal of grain production, contribution of soil available nutrients, contribution of fertilizer nutrients and contribution of farm yard manure were worked out. It was found that hybrid maize requires $1.76,0.58$ and $1.62 \mathrm{~kg}$ of $\mathrm{N}_{2} \mathrm{P}_{2} \mathrm{O}_{5}$ and $\mathrm{K}_{2} \mathrm{O}$ per quintal of grain produced. Using the basic parameters, fertiliser prescription equations were developed based on integrated plant nutrition system (IPNS). It was estimated that, application of FYM @ $12.5 \mathrm{t} \mathrm{ha}^{-1}$ with $28 \%$ moisture, $0.53 \%, 0.26 \%$ and $0.50 \%$ of $\mathrm{N}, \mathrm{P}$ and $\mathrm{K}$, respectively along with NPK fertilizers, the extent of saving inorganic fertiliser for hybrid maize was 40,20 and $30 \mathrm{~kg}$ of fertiliser $\mathrm{N}, \mathrm{P}_{2} \mathrm{O}_{5}$ and $\mathrm{K}_{2} \mathrm{O}$, respectively. Thus to maintain consistent soil fertility with high rate of productivity soil test based fertiliser recommendation along with integrated nutrient management will benefit the farmer in saving of fertilizer and sustaining soil health.

\section{Introduction}

Efficient nutrient management necessitates balanced fertiliser use and sound management decisions and practices to the productivity of maize and sustained soil fertility. Maize is the third most important food grain in India after wheat and rice. It is a versatile cereal crop which is cultivated widely throughout the world and has the highest production among all the cereals. Soil test based nutrient management practices provide better productivity, profitability, sustainability and environmental safety (Venugopalan et al., 2011).
The fertilizer recommendation should effectively consider the crop needs and nutrients available in the soil before (Anon, 1997). Among the various methods, the soil test crop response approach (STCR) for targeted yield is found to be indicating the unique features like soil test based fertiliser dose and levels of yields that can be achieved. Insufficient nutrient additions compared to nutrient uptake leads to a decline in soil fertility.

The present investigation was carried out with an objective to evolve the sound basis of fertilizer prescriptions for maize crop in 
mixed black calcareous soil (Inceptisol) under the conditions of fertilizer scarcity and to ensure maximum fertilizer use efficiency. To maintain the yield level and to sustain soil fertility, an attempt was made to refine fertiliser prescription equation developed for maize variety in Periyanaickenpalayam series to suit hybrid maize. The fertilizer prescription equations developed using this model can be applied to Periyanaickenpalayam soil series and to the similar soil series of other regions by substituting the soil nutrient status of the particular field.

\section{Materials and Methods}

The study was conducted in Allapalayam village, Annur block, Coimbatore District of Tamil Nadu, India for the year 2015 to 2016. The experiment was conducted in the farmer's field of Periyanaickenpalayam soil series (mixed black calcareous soil) with the test crop as TNAU maize hybrid CO 6.

The crop received one fourth $\mathrm{N}$ and full dose of $\mathrm{P}_{2} \mathrm{O}_{5}$ and $\mathrm{K}_{2} \mathrm{O}$ as basal application and remaining half and one fourth $\mathrm{N}$ were applied at 25 days after sowing (DAS) and 45 DAS respectively. Nitrogen was applied through urea, phosphorus through diammonium phosphate (DAP) and potassium through muriate of potash.

The surface soil $(0-15 \mathrm{~cm})$ of the experimental field is mixed black calcareous, sandy clay loam in texture with $\mathrm{pH} 8.10$ and electrical conductivity (EC) of $0.13 \mathrm{dS} \mathrm{m} \mathrm{m}^{-1}$. The initial soil available nutrient viz., alkaline $\mathrm{KMnO}_{4}-\mathrm{N}$ (Subbiah and Asija, 1956), Olsen$\mathrm{P}$ (Olsen et al., 1954) and $\mathrm{NH}_{4} \mathrm{OAc}-\mathrm{K}$ (Stanford and English, 1949) were 162, 16.5 and $430\left(\mathrm{~kg} \mathrm{ha}^{-1}\right)$ respectively.

The initial soil test values were low organic carbon and available $\mathrm{N}$ and medium available $P$ and high available $K$ and sufficient in available $\mathrm{Cu}, \mathrm{Mn}, \mathrm{Fe}, \mathrm{Zn}$.

The treatments include $\mathrm{T}_{1}$-STCR-NPK alone$100 \%$ of FD for $5 \mathrm{t} \mathrm{ha}^{-1}, \mathrm{~T}_{2}$-STCR-NPK alone- $125 \%$ of FD for $5 \mathrm{t} \mathrm{ha}^{-1}, \mathrm{~T}_{3}$-STCRNPK alone- $150 \%$ of FD for $5 \mathrm{t} \mathrm{ha}^{-1}, \mathrm{~T}_{4}$ STCR-NPK alone- $175 \%$ of FD for $5 \mathrm{t} \mathrm{ha}^{-1}$, $\mathrm{T}_{5}$-STCR-NPK alone- $200 \%$ of FD for $5 \mathrm{t}$ $\mathrm{ha}^{-1}, \quad \mathrm{~T}_{6}$-STCR-IPNS - $100 \%$ of FD for $5 \mathrm{t}$ $\mathrm{ha}^{-1}+\mathrm{FYM} @ 12.5 \mathrm{t} \mathrm{ha}^{-1}, \mathrm{~T}_{7}$-STCR-IPNS $125 \%$ of FD for $5 \mathrm{tha}^{-1}+$ FYM @ $12.5 \mathrm{t} \mathrm{ha}^{-1}$, $\mathrm{T}_{8}$-STCR-IPNS - $150 \%$ of FD for $5 \mathrm{t} \mathrm{ha}^{-1}+$ FYM @ $12.5 \mathrm{t} \mathrm{ha}^{-1}, \mathrm{~T}_{9}$-STCR-IPNS - $175 \%$ of FD for $5 \mathrm{t} \mathrm{ha}^{-1}+\mathrm{FYM} @ 12.5 \mathrm{t} \mathrm{ha}^{-1}, \mathrm{~T}_{10^{-}}$ STCR-IPNS - $200 \%$ of FD for $5 \mathrm{tha}^{-1}+$ FYM @ $12.5 \mathrm{t} \mathrm{ha}^{-1}, \mathrm{~T}_{11}$-FYM @ 6.25 t ha ${ }^{-1}$ alone, $\mathrm{T}_{12}$-FYM @ $12.5 \mathrm{t} \mathrm{ha}^{-1}$ alone, $\mathrm{T}_{13}$-Absolute control.

The experiment was laid out in Randomized block design with three replications. Crop was harvested, grain and straw yield were recorded. Plant samples were analysed for total N, P and K. Soil samples were analysed for chemical properties and available macro nutrients.

The fertilizer prescription equations with and without FYM were developed for maize grain by using basic data NR, $\mathrm{C}_{\mathrm{s}}, \mathrm{C}_{\mathrm{f}}$ were calculated by adopting the methodology by Ramamoorthy et al., (1967) and those from $\mathrm{C}_{\text {fym }}$ were estimated as described by Santhi et al.,(1999).

The methodology adopted in the present investigation viz., the prescription procedure outlined by Truog (1960) and modified by Ramamoorthy et al., (1967) as "Inductive cum Targeted yield model".

\section{Nutrient Requirement (NR)}

Nutrient requirement is calculated as $\mathrm{kg}$ of $\mathrm{N} /$ $\mathrm{P}_{2} \mathrm{O}_{5} / \mathrm{K}_{2} \mathrm{O}$ required per quintal $(100 \mathrm{~kg})$ of Grain, expressed in $\left(\mathrm{kg} \mathrm{q}^{-1}\right)$. 
$\mathrm{NR}=\left(\right.$ Total uptake of $\mathrm{N}$ or $\mathrm{P}_{2} \mathrm{O}_{5}$ or $\mathrm{K}_{2} \mathrm{O}(\mathrm{kg}$ $\left.\mathrm{ha}^{-1}\right)$ ) / Grain yield $\left(\mathrm{q} \mathrm{ha}^{-1}\right)$.

Per cent contribution of nutrients from soil to total nutrient uptake (Cs)

$\mathrm{C}_{\mathrm{s}}=\left[\right.$ (Total uptake of $\mathrm{N}$ or $\mathrm{P}_{2} \mathrm{O}_{5}$ or $\mathrm{K}_{2} \mathrm{O}$ in control plot $\left(\mathrm{kg} \mathrm{ha}^{-1}\right)$ ) / (Soil test value for available Nor $\mathrm{P}_{2} \mathrm{O}_{5}$ or $\mathrm{K}_{2} \mathrm{O}$ in control plot $(\mathrm{kg}$ $\left.\left.\left.\mathrm{ha}^{-1}\right)\right)\right]^{*} 100$.

Per cent contribution of nutrients from fertilizer to total uptake (Cf)

$\mathrm{C}_{\mathrm{f}}=\left\{\left[\left(\right.\right.\right.$ Total uptake of $\mathrm{N}$ or $\mathrm{P}_{2} \mathrm{O}_{5}$ or $\mathrm{K}_{2} \mathrm{O}$ in treated plot $\left(\mathrm{kg} \mathrm{ha}^{-1}\right)$ ) - (Soil test value for available $\mathrm{N}$ or $\mathrm{P}_{2} \mathrm{O}_{5}$ or $\mathrm{K}_{2} \mathrm{O}$ in control plot $(\mathrm{kg}$ $\mathrm{ha}^{-1}$ ) * Average Cs)] / Fertilizer $\mathrm{N}$ or $\mathrm{P}_{2} \mathrm{O}_{5}$ or $\mathrm{K}_{2} \mathrm{O}$ applied $\left.\left(\mathrm{kg} \mathrm{ha}^{-1}\right)\right\} * 100$.

Percent contribution of nutrients from organics to total uptake (Co)

\section{Percent contribution from FYM (Cfym)}

$\mathrm{C}_{\text {fym }}=\{[($ Total uptake of $\mathrm{N}$ or $\mathrm{P}$ or $\mathrm{K}$ in FYM treated plot $\left.\left(\mathrm{kg} \mathrm{ha}^{-1}\right)\right)$ - (Soil test value for available $\mathrm{N}$ or $\mathrm{P}$ or $\mathrm{K}$ in FYM treated plot $(\mathrm{kg}$ ha $^{-1}$ ) * Average Cs)] / Nutrient N/P/K added through FYM $\left.\left(\mathrm{kg} \mathrm{ha}^{-1}\right)\right\} * 100$

These parameters were used for developing fertilizer prescription equations for deriving fertilizers doses, and the soil test based fertilizer recommendations were prescribed in the form of a ready table for desired yield target of maize grain under NPK alone as well as under IPNS.

\section{Fertilizer prescription equations}

Making use of these parameters, the fertilizer prescription equations (FPEs) were developed for hybrid maize as furnished below.

\section{Fertilizer nitrogen $(\mathrm{FN})$}

$\mathrm{FN}=\left\{[(\mathrm{NR} /(\mathrm{Cf} / 100)) * \mathrm{~T}]-\left[(\mathrm{Cs} / \mathrm{Cf})^{*} \mathrm{SN}\right]\right\}$
$\mathrm{FN}=\left\{\left[(\mathrm{NR} /(\mathrm{Cf} / 100))^{*} \mathrm{~T}\right]-[(\mathrm{Cs} / \mathrm{Cf}) * \mathrm{SN}]-\right.$ $[(\mathrm{Cfym} / \mathrm{Cf}) * \mathrm{ON}]\}$

Fertilizer phosphorus $\left(\mathrm{FP}_{2} \mathrm{O}_{5}\right)$

$\mathrm{FP}_{2} \mathrm{O}_{5}=\{[(\mathrm{NR} \quad / \quad(\mathrm{Cf} / 100)) * \mathrm{~T}]$
$[(\mathrm{Cs} / \mathrm{Cf}) * 2.29 \mathrm{SP}]\}$
$\mathrm{FP}_{2} \mathrm{O}_{5}=\{[(\mathrm{NR} \quad / \quad(\mathrm{Cf} / 100)) * \mathrm{~T}]-$
$[(\mathrm{Cs} / \mathrm{Cf}) * 2.29 \mathrm{SP}]-[(\mathrm{Cfym} / \mathrm{Cf}) * 2.29 \mathrm{OP}]\}$

Fertilizer potassium $\left(\mathrm{FK}_{2} \mathrm{O}\right)$

$\mathrm{FK}_{2} \mathrm{O}=\{[(\mathrm{NR} /(\mathrm{Cf} / 100)) * \mathrm{~T}]-$ $[(\mathrm{Cs} / \mathrm{Cf}) * 1.21 \mathrm{SK}]\}$

$\mathrm{FK}_{2} \mathrm{O}=\left\{\left[(\mathrm{NR} \quad / \quad(\mathrm{Cf} / 100))^{*} \mathrm{~T}\right]-\right.$ $\left.[(\mathrm{Cs} / \mathrm{Cf}) * 1.21 \mathrm{SK}]-\left[(\mathrm{Cfym} / \mathrm{Cf})^{*} 1.21 \mathrm{OK}\right]\right\}$

Where, $\mathrm{FN}, \mathrm{FP}_{2} \mathrm{O}_{5}$ and $\mathrm{FK}_{2} \mathrm{O}$ are fertilizer $\mathrm{N}$, $\mathrm{P}_{2} \mathrm{O}_{5}$ and $\mathrm{K}_{2} \mathrm{O}$ in $\mathrm{kg} \mathrm{ha}^{-1}$, respectively; $\mathrm{NR}$ is nutrient requirement $\left(\mathrm{N}\right.$ or $\mathrm{P}_{2} \mathrm{O} 5$ or and $\left.\mathrm{K}_{2} \mathrm{O}\right)$ in $\mathrm{kg} \mathrm{q}^{-1}$, Cs is per cent contribution of nutrients from soil, $\mathrm{Cf}$ is per cent contribution of nutrients from fertilizer, Cfym is percent contribution of nutrients from FYM, T is the yield target in $\mathrm{q} \mathrm{ha}{ }^{-1} ; \mathrm{SN}, \mathrm{SP}$ and $\mathrm{SK}$ respectively are alkaline $\mathrm{KMnO}_{4}-\mathrm{N}$, Olsen-P and $\mathrm{NH}_{4} \mathrm{OAc}-\mathrm{K}$ in $\mathrm{kg} \mathrm{ha}^{-1}$ and $\mathrm{ON}$, OP and $\mathrm{OK}$ are the quantities of $\mathrm{N}, \mathrm{P}$ and $\mathrm{K}$ supplied through FYM in $\mathrm{kg} \mathrm{ha}^{-1 .}$

These equations serve as a basis for predicting fertilizer doses for specific yield targets $(\mathrm{T})$ of hybrid maize for varied soil available nutrient levels.

\section{Results and Discussion}

\section{Grain yield}

Grain yield of the hybrid maize ranged from $5313 \mathrm{Kg} \mathrm{ha}^{-1}$ to $12032 \mathrm{Kg} \mathrm{ha}^{-1}$ (Table 1). The $\mathrm{N}$ uptake of hybrid maize ranges from 54.39 $\mathrm{Kg} \mathrm{ha}^{-1}$ to $241.82 \mathrm{Kg} \mathrm{ha}^{-1}$ whereas $\mathrm{P}$ and $\mathrm{K}$ uptake ranged from $6.30 \mathrm{Kg} \mathrm{ha}^{-1}$ to $33.57 \mathrm{Kg}$ $\mathrm{ha}^{-1}$ and $71.10 \mathrm{Kg} \mathrm{ha}{ }^{-1}$ to $149.36 \mathrm{Kg} \mathrm{ha}^{-1}$ 
respectively (Table 1). The results indicated that, maize is an exhaustive crop requires relatively higher nutrient level and also the enhanced grain yield was achieved when there is a consistent supply of nutrients. Application of NPK fertlisers along with FYM might have provided a desirable soil condition for the root development, enhancing nutrient uptake, crop growth and yield of rice (Santhi et al., 1998). The present study emphasis that along with inorganic fertlisers, organic manures also necessary to maintain optimum rhizosphere environment for sustaining maize grain yield at higher level. This study also confirms the role of FYM and chemical fertiliser combinations in increasing grain yield of maize and the results showed that manure and chemical fertiliser can increase grain yield of maize but a combination of them have more effect on increase in grain yield (Bekeo, 2013).

\section{Nutrient uptake}

The N, P and K uptake ranged from 54.39 to $241.82 \mathrm{~kg} \mathrm{ha}^{-1}, 6.30$ to $33.57 \mathrm{~kg} \mathrm{ha}^{-1}$ and 71.10 to $151.52 \mathrm{~kg} \mathrm{ha}^{-1}$, respectively. Among the treatments, STCR-IPNS-200\% of FD for 5 $\mathrm{t} \mathrm{ha}^{-1}+\mathrm{FYM} @ 12.5 \mathrm{t} \mathrm{ha}^{-1}\left(\mathrm{~T}_{10}\right)$ recorded the highest total $\mathrm{N}$ uptake $\left(241.82 \mathrm{~kg} \mathrm{ha}^{-1}\right), \mathrm{P}$ uptake $\left(33.57 \mathrm{~kg} \mathrm{ha}^{-1}\right)$ and $\mathrm{K}$ uptake (151.52 $\mathrm{kg} \mathrm{ha}^{-1}$ ) (Table 1). Among the treatments, STCR-IPNS treatment with STCR-IPNS- 200 $\%$ FD for $5 \mathrm{t} \mathrm{ha}^{-1}+\mathrm{FYM} @ 12.5 \mathrm{t} \mathrm{ha}^{1}\left(\mathrm{~T}_{10}\right)$ recorded significant and the highest total uptake of $\mathrm{N}$. Whereas, the total uptake of $\mathrm{P}$ and $\mathrm{K}$ was found to be the highest in STCRIPNS- $200 \%$ FD for $5 \mathrm{t} \mathrm{ha}^{-1}+\mathrm{FYM} @ 12.5 \mathrm{t}$ ha- ${ }^{1}\left(\mathrm{~T}_{10}\right)$ followed by STCR-IPNS-175 \% FD for $5 \mathrm{t} \mathrm{ha}^{-1}+\mathrm{FYM} @ 12.5 \mathrm{t} \mathrm{ha}^{1}{ }^{1}\left(\mathrm{~T}_{9}\right)$ which were on par with each other. STCR-IPNS treatments were found to dominate over STCR-NPK alone treatments.

The improved nutrient uptake in FYM amended plots could be attributed to enhanced organic matter decomposition-mineralization process, better root development and higher nutrient availability (Khan et al., 2009). Similar pattern of response were reported by Tanwar (2014) with combination of manures and fertlisers. Application of organic manures not only increases the uptake of primary nutrients and also enhances the uptake of secondary nutrients (Tanwar, 2014). Absolute control recorded the lowest NPK uptake emphasizing continuous cropping without addition of mineral fertilisers or manures retard the yield of maize due to the poor dry matter production and degrade soil quality in long run.

\section{Response of hybrid maize to fertilizer applied}

In optimization of fertiliser dose, response of maize to fertilisers levels play a crucial role. The response of hybrid maize to different graded levels of fertilizer $\mathrm{N}, \mathrm{P}_{2} \mathrm{O}_{5}$ and $\mathrm{K}_{2} \mathrm{O}$ were assessed in terms of Response ratio (RR). The response varied from $1061 \mathrm{~kg} \mathrm{ha}^{-}$ ${ }^{1}$ in FYM @ $6.25 \mathrm{t} \mathrm{ha}^{-1}$ to $6829 \mathrm{~kg} \mathrm{ha}^{-1}$ in STCRIPNS-200\% of FD for $5 \mathrm{t} \mathrm{ha}^{-1}+$ FYM @ $12.5 \mathrm{t}$ $\mathrm{ha}^{-1}$ (Table 1). There was a linear increase in response to applied nutrients under STCRNPK alone and it was at diminishing rate with increasing fertiliser levels which might be due to the increase in fertiliser doses at higher target levels. Under IPNS, the response increased upto STCR-IPNS-200\% of FD for 5 $\mathrm{t} \mathrm{ha}^{-1}+$ FYM@12.5 $\mathrm{t} \mathrm{ha}^{-1}$.The magnitude of response was greater under STCR-IPNS treatments when compared to STCR-NPK alone. Similar trend of results was recorded by Coumarvel et al., (2016). The positive response to higher level of fertilisers on grain yield to be ascribed to the overall improvement in crop growth enabled the plant to absorb more nutrients which empowered the plant to synthesize more quantity of photosynthate and accumulating in sink which are converted in to economic yield of grain maize (Joshi et al., 2013; Kadlag and Godke, 2013). 


\section{Basic parameters}

\section{Nutrient Requirement}

Adoption of appropriate site and situation specific nutrient prescriptions will become one of the technological interventions for boosting the yield of maize in the sequence. Nutrient requirement to produce one quintal of hybrid maize $1.76 \mathrm{Kg}$ of $\mathrm{N}, 0.58 \mathrm{Kg}$ of $\mathrm{P}_{2} \mathrm{O}_{5}$ and 1.62 $\mathrm{Kg}$ of $\mathrm{K}_{2} \mathrm{O}$ (Table 2) and (Fig. 1). Relatively, higher quantity of $\mathrm{N}$ was required followed by $\mathrm{K}_{2} \mathrm{O}$ and $\mathrm{P}_{2} \mathrm{O}_{5}$ to produce unit quantity of hybrid maize. The requirement of $\mathrm{N}$ was 1.08 times higher than $\mathrm{K}$ and 3.03 times higher than $\mathrm{P}_{2} \mathrm{O}_{5}$. Similar trend of nutrient requirement for $\mathrm{N}, \mathrm{P}_{2} \mathrm{O}_{5}$ and $\mathrm{K}_{2} \mathrm{O}$ was also reported by Coumarvel (2012) for maize in Palaviduthi soil series (Typic Rhodustalf) in Tamil Nadu and Singh et al., (2015) for maize at Varanasi in Inceptisol.

Fig.1 Nutrient requirement $\left(\mathrm{kg} \mathrm{q}^{-1}\right)$ to hybrid maize

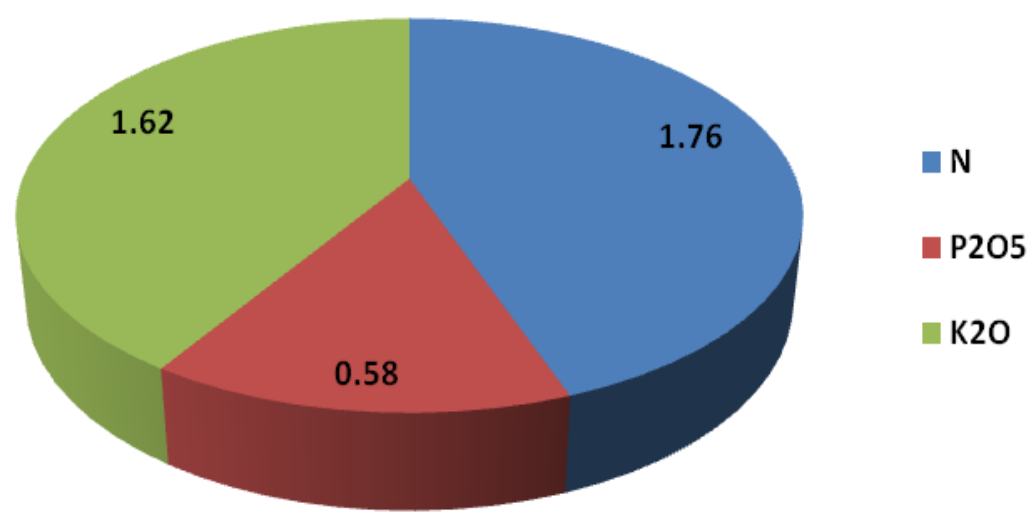

Fig.2 Per cent contribution from soil, fertilizer and FYM

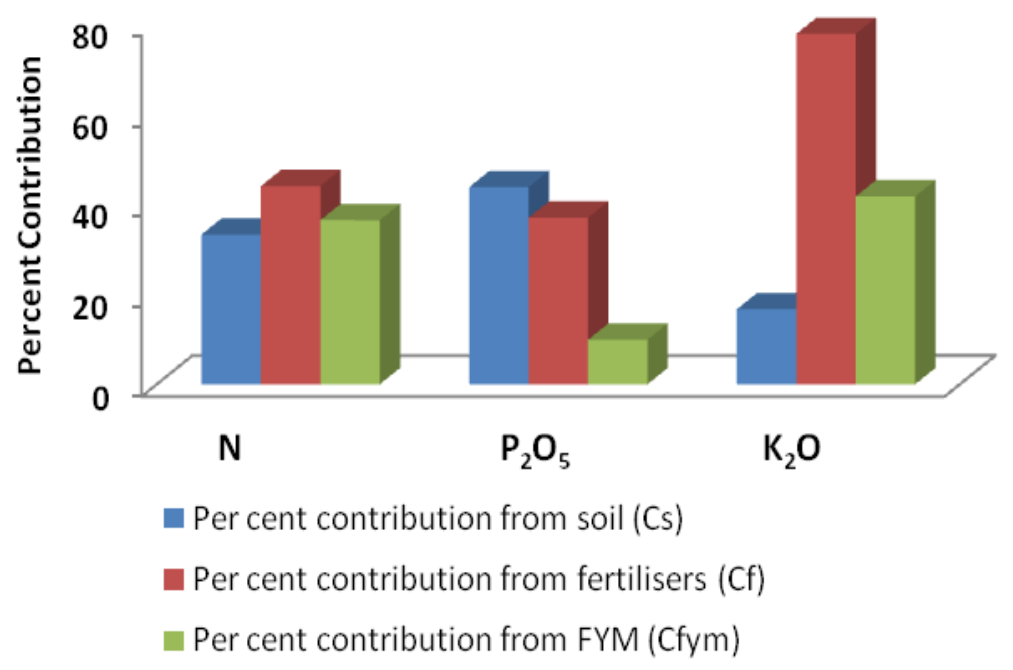




\section{Fertilizer prescription equations for Hybrid maize}

\begin{tabular}{|l|l|}
\hline STCR- NPK alone & STCR-(NPK + FYM) \\
\hline $\mathrm{FN}=4.01 \mathrm{~T}-0.76 \mathrm{SN}$ & $\mathrm{FN}=4.01 \mathrm{~T}-0.76 \mathrm{SN}-0.83 \mathrm{ON}$ \\
\hline $\mathrm{FP}_{2} \mathrm{O}_{5}=1.57 \mathrm{~T}-2.71 \mathrm{SP}$ & $\mathrm{FP}_{2} \mathrm{O}_{5}=1.57 \mathrm{~T}-2.71 \mathrm{SP}-0.61 \mathrm{OP}$ \\
\hline $\mathrm{FK}_{2} \mathrm{O}=2.09 \mathrm{~T}-0.26 \mathrm{SK}$ & $\mathrm{FK}_{2} \mathrm{O}=2.09 \mathrm{~T}-0.26 \mathrm{SK}-0.65 \mathrm{OK}$ \\
\hline
\end{tabular}

Table.1 Experimental data for refinement of fertiliser prescription equations for maize (Mean of three replications)

\begin{tabular}{|c|c|c|c|c|c|c|c|c|c|c|c|c|}
\hline \multirow[t]{2}{*}{$\begin{array}{l}\text { Sl. } \\
\text { No. }\end{array}$} & \multirow[t]{2}{*}{ Treatment } & $\begin{array}{l}\text { Grain } \\
\text { Yield } \\
\end{array}$ & UN & UP & UK & \begin{tabular}{|l|} 
SN \\
\end{tabular} & SP & SK & FN & $\mathrm{FP}_{\mathbf{2}} \mathrm{O}_{\mathbf{5}}$ & $\mathrm{FK}_{2} \mathrm{O}$ & \multirow{2}{*}{$\begin{array}{l}\text { FYM } \\
\left(\begin{array}{c}\text { t ha } \\
\left.{ }^{\prime}\right)\end{array}\right.\end{array}$} \\
\hline & & \multicolumn{10}{|c|}{ - } & \\
\hline 1 & $\begin{array}{l}\text { STCR-NPK alone- } 100 \\
\% \text { of FD for } 5 \mathrm{t} \mathrm{ha}^{-1}\end{array}$ & 8148 & 142.63 & 20.90 & 115.76 & 164 & 16.0 & 435 & 203 & 87 & 67 & - \\
\hline 2 & $\begin{array}{l}\text { STCR-NPK alone-125 } \\
\% \text { of FD for } 5 \mathrm{t} \mathrm{h}^{-1}\end{array}$ & 8704 & 168.04 & 24.09 & 128.48 & 164 & 15.5 & 435 & 254 & 109 & 83 & - \\
\hline 3 & $\begin{array}{l}\text { STCR-NPK alone-150 } \\
\% \text { of FD for } 5 \mathrm{tha}^{-1}\end{array}$ & 9683 & 185.85 & 27.49 & 138.27 & 166 & 15.6 & 435 & 304 & 131 & 100 & - \\
\hline 4 & $\begin{array}{l}\text { STCR-NPK alone }-175 \\
\% \text { of FD for } 5 \mathrm{t} \mathrm{ha}^{-1}\end{array}$ & 10278 & 197.57 & 28.88 & 147.65 & 166 & 15.6 & 437 & 355 & 153 & 116 & - \\
\hline 5 & $\begin{array}{l}\text { STCR-NPK alone- } 200 \\
\% \text { of FD for } 5 \mathrm{t} \mathrm{ha}^{-1}\end{array}$ & 10486 & 204.34 & 30.20 & 151.52 & 165 & 16.1 & 435 & 406 & 174 & 133 & - \\
\hline 6 & $\begin{array}{l}\text { STCR-IPNS - } 100 \% \text { of } \\
\text { FD for } 5 \mathrm{tha}^{-1}+\mathrm{FYM} \\
@ 12.5 \mathrm{tha}^{-1}\end{array}$ & 9245 & $\mid 170.29$ & 25.54 & 113.79 & 166 & $\mid 16.0$ & 438 & 203 & 87 & 67 & 12.5 \\
\hline 7 & $\begin{array}{l}\text { STCR-IPNS }-125 \% \text { of } \\
\text { FD for } 5 \mathrm{tha}^{-1}+\mathrm{FYM} \\
@ 12.5 \mathrm{tha}^{-1}\end{array}$ & 10203 & $\mid 190.31$ & 28.20 & 125.68 & 166 & $\mid 15.8$ & 439 & 254 & 109 & 83 & 12.5 \\
\hline 8 & $\begin{array}{l}\text { STCR-IPNS }-150 \% \text { of } \\
\text { FD for } 5 \mathrm{tha}^{-1}+\mathrm{FYM} \\
@ 12.5 \mathrm{tha}^{-1}\end{array}$ & 10992 & 210.20 & 30.82 & 135.85 & 166 & 16.4 & 439 & 304 & 131 & 100 & 12.5 \\
\hline 9 & $\begin{array}{l}\text { STCR-IPNS }-175 \% \text { of } \\
\text { FD for } 5 \mathrm{tha}^{-1}+\mathrm{FYM} \\
@ 12.5 \mathrm{tha}^{-1}\end{array}$ & 11393 & 226.50 & 32.35 & 143.63 & 166 & $\mid 16.6$ & 437 & 355 & 153 & 116 & 12.5 \\
\hline 10 & $\begin{array}{l}\text { STCR-IPNS -200\% of } \\
\text { FD for } 5 \mathrm{tha}^{-1}+\mathrm{FYM} \\
@ 12.5 \mathrm{tha}^{-1}\end{array}$ & 12032 & 241.82 & 33.57 & 149.36 & 166 & 16.4 & 439 & 406 & 174 & 133 & 12.5 \\
\hline 11 & $\begin{array}{l}\text { FYM } \\
\text { alone }\end{array}$ & 6234 & 64.03 & 7.84 & 81.05 & 166 & 16.4 & 435 & 24 & 17 & 23 & 6.25 \\
\hline 12 & $\begin{array}{lllll}\begin{array}{l}\text { FYM } \\
\text { alone }\end{array} & @ & 12.5 & \mathrm{t} & \mathrm{ha}^{-1} \\
\end{array}$ & 6625 & $\mid 71.20$ & 8.63 & 90.39 & 165 & 16.4 & 436 & 48 & 33 & 46 & 12.5 \\
\hline 13 & Absolute Control. & 3 & 54.39 & 6.30 & 71.10 & 164 & $\mid 16.4$ & 428 & & & & \\
\hline & Mean & 9 & 163.31 & 23.44 & 122.50 & 165 & $\mid 16.0$ & 436 & & & & \\
\hline & SEd & 174.40 & 4.54 & 0.90 & 3.40 & & & & & & & \\
\hline & $\mathrm{CD}(\mathrm{p}=0.05)$ & 359.95 & 9.37 & 1.86 & 7.01 & & & & & & & \\
\hline
\end{tabular}


Table.2 Basic parameters for maize and Fertiliser prescription equations

\begin{tabular}{|l|c|c|c|}
\hline \multirow{2}{*}{\multicolumn{1}{|c|}{ Parameters }} & \multicolumn{3}{c|}{ Basic data } \\
\cline { 2 - 4 } & $\mathbf{N}$ & $\mathbf{P}_{\mathbf{2}} \mathbf{O}_{\mathbf{5}}$ & $\mathbf{K}_{\mathbf{2}} \mathbf{O}$ \\
\hline Nutrient requirement $\left(\mathrm{kg} \mathrm{q}^{-1}\right)$ & 1.76 & 0.58 & 1.62 \\
\hline Per cent contribution from soil (Cs) & 33.16 & 43.66 & 16.61 \\
\hline Per cent contribution from fertilisers (Cf) & 43.91 & 36.90 & 77.63 \\
\hline Per cent contribution from FYM (Cfym) & 36.35 & 9.85 & 41.60 \\
\hline
\end{tabular}

Table.3 Soil test based fertiliser $\mathrm{N} / \mathrm{P}_{2} \mathrm{O}_{5} / \mathrm{K}_{2} \mathrm{O}$ for desired yield targets of maize under NPK alone and IPNS $\left(\mathrm{kg} \mathrm{ha}^{-1}\right)$

\begin{tabular}{|c|c|c|c|}
\hline \multirow[b]{2}{*}{$\begin{array}{c}\text { Fertilisers } \\
\left(\mathbf{k g ~ h a}^{-1}\right)\end{array}$} & \multicolumn{3}{|c|}{ Treatments } \\
\hline & NPK alone & $\underset{\text { ha }^{-1}}{\mathrm{NPK}+\mathrm{FYM}} \mathbf{1 2 . 5 \mathrm { t }}$ & $\begin{array}{l}\text { Per cent reduction } \\
\text { due to IPNS over } \\
\text { NPK alone }\end{array}$ \\
\hline \multicolumn{4}{|c|}{$10 \mathrm{t} \mathrm{ha}^{-1} \mathrm{KMnO}_{4}-\mathrm{N}\left(\mathrm{kg} \mathrm{ha}^{-1}\right)$} \\
\hline 150 & 288 & 248 & 13.76 \\
\hline 175 & 269 & 229 & 14.73 \\
\hline 200 & 250 & 211 & 15.84 \\
\hline 225 & 231 & 192 & 17.13 \\
\hline 250 & 212 & 173 & 18.65 \\
\hline 275 & 194 & 154 & 20.47 \\
\hline \multicolumn{4}{|c|}{$10 \mathrm{t} \mathrm{ha}^{-1}$ Olsen $\mathrm{P}\left(\mathrm{kg} \mathrm{ha}^{-1}\right)$} \\
\hline 12 & 125 & 104 & 16.19 \\
\hline 14 & 119 & 99 & 16.93 \\
\hline 16 & 114 & 94 & 17.73 \\
\hline 18 & 108 & 88 & 18.62 \\
\hline 20 & 103 & 83 & 19.60 \\
\hline 22 & 98 & 77 & 20.69 \\
\hline \multicolumn{4}{|c|}{$10 \mathrm{tha}^{-1} \mathrm{NH}_{4} \mathrm{OAC}-\mathrm{K}\left(\mathrm{kg} \mathrm{ha}^{-1}\right)$} \\
\hline 350 & 118 & 89 & 24.98 \\
\hline 375 & 112 & 82 & 26.43 \\
\hline 400 & 105 & 76 & 28.06 \\
\hline 425 & 99 & 69 & 29.89 \\
\hline 450 & 92 & 63 & 31.99 \\
\hline 475 & 86 & 56 & 34.40 \\
\hline
\end{tabular}

Percent contribution of nutrients from soil (Cs)

The ability of the crop to remove nutrients from the soil has been calculated in terms of the per cent contribution of nutrients from soil (Cs) to the total uptake in absolute control plots. In the present investigation, it was found that the soil has contributed 33.16 per cent of available $\mathrm{N}, 43.66$ per cent of $\mathrm{P}_{2} \mathrm{O}_{5}$ and 16.61 per cent of $\mathrm{K}_{2} \mathrm{O}$ (Table 2) and (Fig. 2) respectively towards the total $\mathrm{N}, \mathrm{P}$ and $\mathrm{K}$ uptake by hybrid maize.

Among the three nutrients, relative supply of nutrients was in the order of $\mathrm{P}>\mathrm{N}>\mathrm{K}$. Similar 
findings were reported by Praveena Katharine et al., (2013) for cotton in Periyanaickenpalayam soil series (Typic Ustropept) of Tamil Nadu.

\section{Percent contribution of nutrients from fertiliser (Cf)}

The per cent contribution of nutrients from fertiliser nutrients (Cf) towards the total uptake by hybrid maize was 43.91, 36. 90 and 77.63 per cent (Table 2) and (Fig. 2) respectively for $\mathrm{N}, \mathrm{P}_{2} \mathrm{O}_{5}$ and $\mathrm{K}_{2} \mathrm{O}$ and followed the order of $\mathrm{K}_{2} \mathrm{O}>\mathrm{N}>\mathrm{P}_{2} \mathrm{O}_{5}$.

The estimated per cent contribution of nutrients from fertilisers (Cf) to total uptake clearly revealed that the amount of contribution by fertiliser $\mathrm{K}_{2} \mathrm{O}$ was 1.76 times higher than $\mathrm{N}$ and 2.10 times as that of $\mathrm{P}_{2} \mathrm{O}_{5}$.

\section{Contribution of nutrient from FYM}

The per cent contribution of $\mathrm{N}, \mathrm{P}_{2} \mathrm{O}_{5}$ and $\mathrm{K}_{2} \mathrm{O}$ from FYM (Cfym) was computed in the present investigation to evaluate the extent of reduction in NPK fertiliser requirements of hybrid maize through IPNS.

The estimated per cent contribution of $\mathrm{N}$, $\mathrm{P}_{2} \mathrm{O}_{5}$ and $\mathrm{K}_{2} \mathrm{O}$ from FYM (Cfym) were 36.35 , 9.85 and 41.60 (Table 2) and (Fig. 2) respectively for hybrid maize which indicated that relatively higher contribution was recorded for $\mathrm{N}$ and $\mathrm{K}_{2} \mathrm{O}$ followed by $\mathrm{P}_{2} \mathrm{O}_{5}$.

The present findings corroborated with the findings of Praveena Katharine et al., (2013) and Singh et al., (2015).

\section{Fertilizer prescription equations for Hybrid maize}

Where, $\mathrm{FN}, \mathrm{FP}_{2} \mathrm{O}_{5}$ and $\mathrm{FK}_{2} \mathrm{O}$ are fertilizer $\mathrm{N}$, $\mathrm{P}_{2} \mathrm{O}_{5}$ and $\mathrm{K}_{2} \mathrm{O}$ in kg ha ${ }^{-1}$, respectively; $\mathrm{T}$ is the grain yield target in $\mathrm{q} \mathrm{ha}^{-1} ; \mathrm{SN}, \mathrm{SP}$ and $\mathrm{SK}$ respectively are alkaline $\mathrm{KMnO}_{4}-\mathrm{N}$, Olsen-P and $\mathrm{NH}_{4} \mathrm{OAc}-\mathrm{K}$ in $\mathrm{kg} \mathrm{ha}{ }^{-1}$ and $\mathrm{ON}$, OP and $\mathrm{OK}$ are the quantities of $\mathrm{N}, \mathrm{P}$ and $\mathrm{K}$ supplied through FYM in $\mathrm{kg} \mathrm{ha}^{-1}$.

Soil test based fertiliser doses for desired yield targets of hybrid maize (TNAU Maize Hybrid CO 6) under IPNS

Ready reckoner of fertiliser doses (nomograms) were formulated for desired yield targets of maize, (TNAU Maize Hybrid CO 6) for a range of soil test values under IPNS (NPK plus FYM @ $12.5 \mathrm{t} \mathrm{ha}^{-1}$ ). Using the fertiliser prescription equations under IPNS, the extent of saving of chemical fertilisers was computed. The results showed that with the application of FYM @ $12.5 \mathrm{tha}^{-}$ ${ }^{1}$ (with $28 \%$ moisture, $0.53 \%, 0.26 \%$ and $0.50 \%$ NPK, respectively), there was a saving of 40,20 and $30 \mathrm{~kg}$ of fertiliser $\mathrm{N}$, $\mathrm{P}_{2} \mathrm{O}_{5}$ and $\mathrm{K}_{2} \mathrm{O}$, respectively. In general, depending on the moisture and $\mathrm{N}, \mathrm{P}$ and $\mathrm{K}$ contents of FYM at the time of application, the corresponding quantities of nutrients in terms of fertiliser $\mathrm{N}, \mathrm{P}_{2} \mathrm{O}_{5}$ and $\mathrm{K}_{2} \mathrm{O}$ can be deducted from the recommended doses of nutrients. To obtain an yield target of $10 \mathrm{t} \mathrm{ha}^{-1}$ with a soil test value of 200,16 and $400 \mathrm{~kg}$ of $\mathrm{N}, \mathrm{P}$ and $\mathrm{K} \mathrm{ha}^{-1}, 250,114$ and $105 \mathrm{~kg}$ of $\mathrm{N}$, $\mathrm{P}_{2} \mathrm{O}_{5}$ and $\mathrm{K}_{2} \mathrm{O}$ ha $^{-1}$ have to be applied if fertilizers are applied as NPK alone where in IPNS (NPK + 12.5 t FYM ha ${ }^{-1}$ ), 211, 94 and $76 \mathrm{~kg}$ of $\mathrm{N}, \mathrm{P}_{2} \mathrm{O}_{5}$ and $\mathrm{K}_{2} \mathrm{O}$ ha $^{-1}$ is sufficient to produce $10 \mathrm{t} \mathrm{ha}^{-1}$. STCR-IPNS saves 15.84, 17.73 and 28.06 percent of $\mathrm{N}, \mathrm{P}_{2} \mathrm{O}_{5}$ and $\mathrm{K}_{2} \mathrm{O}$ if the contribution of FYM is accounted (Table 3).

In conclusion, STCR-IPNS based fertilizer prescription envisages a balanced form of nutrient supply to the hybrid maize and maintains the soil fertility with magnitude of higher economic production. In the present investigation, soil test based fertilizer prescription equations for desired yield target 
with the graded level fertiliser for hybrid maize was developed using the basic parameters obtained. These fertiliser prescription equations could serve as a basis to prescribe the actual quantities of fertiliser doses under IPNS when FYM was applied along with NPK fertilisers. It was evident that, application of FYM @ $12.5 \mathrm{t} \mathrm{ha}^{-1}$ with $28 \%$ moisture, $0.53 \%, 0.26 \%$ and $0.50 \%$ of $\mathrm{N}$, $\mathrm{P}$ and $\mathrm{K}$, respectively along with NPK fertilizers to hybrid maize can save 40, 20 and $30 \mathrm{~kg}$ of fertiliser $\mathrm{N}, \mathrm{P}_{2} \mathrm{O}_{5}$ and $\mathrm{K}_{2} \mathrm{O}$, respectively in black calcareous soils (Periyenackampalayam soil series- Vertic Ustropept). Thus to maintain consistent soil fertility with high rate of productivity, STCRIPNS based fertilizer prescription becomes essential.

\section{References}

ANONYMOUS. 1997. A Guide to field implementation of integrated plant nutrition system. IFFCO, pp. 55 - 69.

Bekeko. Z. 2013. Improving and sustaining soil fertility by use of enriched farmyard manure and inorganic fertilizers for hybrid maize (BH-140) production at West Hararghe zone,

Oromia, Eastern Ethiopia. Afr. J. Agri. Res., 8(14): 1218-1224.

Coumaravel, K. 2012. Soil Test Crop Response correlation studies through Integrated Plant Nutrition System for Maize-tomato sequence. Ph.D. (Ag.), Thesis submitted to TNAU, Coimbatore.

Coumaravel. K, R. Santhi and S. Maragatham. 2016. Prediction of postharvest soil test values and fertiliser calibrations for maize under integrated Plant nutrition system on alfisol. IJARR, $1(6) ; 146-155$.

Joshi E., V. Nepalia, Arvind Verma and Dilip Singh. 2013. Effect of integrated nutrient management on growth, productivity and economics of maize
(Zea mays). Indian J. Agron., 58 (3): 434- 436.

Kadlag A.D, Ghodke P.D. 2013. Validation of Fertilizer Prescription Equations of Kharif Grain Maize on Different Soil Orders. Online International Interdisciplinary Research Journal, $\{\mathrm{Bi}-$ Monthly\}, III (IV).

Khan, A., M.T. Jan, K.B. Marwat and M. Arif. 2009. Organic and inorganic nitrogen treatments effect on plant and yield attributes of maize in a different tillage system. Pak. J. Bot., 4(1): 99108.

Olsen, S.R., Cole, C.V., Watanabe, F.S. and Dean, L. 1954. Estimation of available phosphorus in soils by extraction with sodium bicarbonate. U.S.D.A. Circ. 939. U.S. Govt. Printing Office, Washington, DC.

Praveena Katharine S., R. Santhi, S. Maragatham, R. Natesan, V. Ravikumar and Pradip Dey. 2013. Soil Test Based Fertilizer Prescriptions Through Inductive Cum Targeted Yield Model for Transgenic Cotton on Inceptisol. IOSR-JAVS, 6(5): 36-44.

Ramamoorthy, B., Narasimham, R. L. and Dinesh, R. S. 1967. Fertilizer application for specific yield targets of Sonora 64 (wheat). Indian Farming, 17: 43-45.

Santhi, R and Selvakumari, G. 1998. Prediction of post-harvest soil test values and fertilizer calibrations for a rice based cropping sequence under integrated plant nutrition system. Oryza 35(3): 246-251.

Santhi, R., Selvakumari, G. and Rani Perumal. 1999. Soil test based fertilizer recommendations under integrated plant nutrition system for rice-rice-pulse cropping sequence. J. Indian Soc. Soil Sci. 47: 288-94.

Singh Y.V, Manoj Parihar, S.K. Singh, P.K. Sharma and Pradip Dey. 2015. Soil Test 
Based Fertilizer Prescriptions under Integrated Plant Nutrient Management System for Maize in an Inceptisol of Varanasi. J. Indian Soc. Soil Sci., 63(1): 83-87.

Stanford, S., English, L. 1949. Use of flame photometer in rapid soil tests of $\mathrm{K}$ and Ca. Agron J 41: 446.

Subbiah, B.V. and Asija, G.L. 1956. A rapid procedure for the estimation of available nitrogen in soils. Curr Sci 25: 259-260.

Tanwar V.S. 2014. Effect of different organic manures and fertilizers on yield and nutrient Uptake of maize (Zea mays L.). Asian J. Sci. and Tech., 5(12): 905-908.

Truog, Fifty years of soil testing, Proc. Trans 7th Intl. Congr. Soil Sci. Vol. III Commission IV paper No.7: 1960, 4653.

Venugopalan, M.V., Blaise, D., Yadav, M.S. and Rachana Deshmukh. 2011. Fertiliser response and nutrient management strategies for cotton. Indian J. Fert., 7(4): 82-94.

\section{How to cite this article:}

Sivaranjani, C., K.M. Sellamuthu and Santhi, R. 2018. Refinement of Fertiliser Prescription Equation for Hybrid Maize under Integrated Plant Nutrient System on an Inceptisol. Int.J.Curr.Microbiol.App.Sci. 7(02): 3670-3679. doi: https://doi.org/10.20546/ijcmas.2018.702.436 